\title{
PERJ ANJ IAN BUILD AND TRANSFER ANTARA PEMERINTAH DAERAH DENGAN PIHAK SWASTA DALAM PENYEDIAAN INFRASTRUKTUR (Studi Di Nusa Tenggara Barat)*
}

\author{
Zainal Asikin \\ Fakultas Hukum Unram \\ E-mail: asikinzainal@yahoo.com
}

Abstract

\begin{abstract}
Undergoing local authority does not always bring with it advantage to the local government, but this may challenge the local government to make efforts to support and fund its governmental development. On of the ways out is by working in cooperation with private enterprises based the law of local execution. This study is intended to analize the cooperative agreement of local government with build and transfer model which is adopted widely by some local governments in Indonesia. Through normative juridical study along with statute and case approaches, it is found the cooperative agreement of build and transfer in Indonesia is ruled by some official regulations which have different substantive points and have conflicted norms and vague rules related to legal subyect, procedures or mechanism of having agreement. In the future it is needed to issue legal decision related to cooperative agreement between the local government and private enterprises which is more comprehensively in order to resolve the legal affairs or disputes.
\end{abstract}

Key words: build and transfer, infrastructure, bouwheer

\begin{abstract}
Abstrak
Pemberian otonomi membawa tantangan bagi daerah untuk mencari dan mengusahakan sendiri sumber keuangan untuk pembiayaan pembangunan. Salah satu cara yang dapat dilakukan adalah melalui kerjasama daerah dengan pihak swasta sebagaimana yang diatur dalam Pasal 192 UU No. 32 Tahun 2004 Tentang Pemerintahan Daerah. Penelitian ini bertujuan untuk menganalisis secara yuridis dan empiris perjanjian kerjasama daerah dengan model build and transfer yang banyak dilakukan di berbagai daerah. Melalui penelitian yuridis normatif, serta dengan pendekatan perundang undangan (statute approach) dan pendekatan kasus (case approach), maka penelitian ini menunjukkan bahwa perjanjian kerjasama build and transfer di Indonesia diatur dalam berbagai perturan hukum yang satu sama lain memiliki substansi yang berbeda dan mengandung konflik norma dan kekaburan hukum yang berkaitan dengan subyek hukum dan mekanisme pembuatan perjanjian. Pada masa yang akan datang diperlukan unifikasi hukum yang mengatur tentang perjanjian kerjasama Pemerintah dalam bentuk Peraturan Pemerintah yang lebih komprehensif agar dapat menjawab persoalan hukum yang terjadi dalam praktik.
\end{abstract}

Kata kunci: build and transfer, infrastruktur, bouwheer

\section{Pendahuluan}

Pembangunan daerah merupakan bagian intergral dan merupakan penjabaran dari pembangunan nasional dalam rangka pencapaian sasaran pembangunan yang disesuaikan dengan potensi, aspirasi dan permasalahan pembangunan di daerah. Kunci keberhasilan pembangunan

- Penelitian ini hasil Kerjasama dengan Lembaga Penelitian Unram (LPM Unram) Tahun 2010-2011 No. Kontrak 010/ LPM-Unram/ 2011 daerah dalam mencapai sasaran pembangunan nasional secara efisien dan efektif, termasuk penyebaran hasilnya secara merata di seluruh Indonesia dan tujuannya yang hakiki dapat terwujud.

Secara filosofis dua tujuan utama yang ingin dicapai dari penerapan kebijakan desentralisasi dan otonomi daerah adalah tujuan: demokrasi dan kesejahteraan. Tujuan demokrasi adalah memposisikan daerah sebagai instru- 
men pendidikan politik di tingkat lokal yang secara agregat akan menyumbang terhadap pendidikan politik secara nasional sebagai elemen dasar dalam menciptakan kesatuan dan persatuan bangsa serta mempercepat terwujudnya masyarakat yang adil, makmur dan sejahtera.

Suatu negara yang menganut kebijakan publik desentralisasi dan otonomi daerah, secara prinsip ditandai dengan adanya penyerahan seba-gian urusan pemerintah (devolution of power) yang sebelumnya menjadi kewenangan pusat kemudian menjadi kewenangan daerah. Ada dua pola yang lazim dipergunakan secara universal, pola pertama yaitu pola otonomi terbatas yaitu kewenangan daerah hanya terbatas pada urusan urusan pemerintahan yang ditetapkan secara limitatif oleh peraturan perundang undangan yang ada sebagaimana dianut oleh Inggris. Urusan pemerintahan yang diserahkan dalam pola otonomi terbatas secara empiris merupakan urusan yang terkait dengan penyelenggaraan pelayanan dasar (basic services) seperti pendidikan, kesehatan, lingkungan, transportasi, perumahan dan urusan yang menyangkut kepentingan lokal lainnya. Pola kedua adalah pola otonomi luas (general competence) yaitu daerah diberikan kewenangan yang luas untuk mengatur dan mengurus urusan pemerintah yang terkait dengan kepentingan masyarakat daerah, kecuali urusan pemerintah yang menimbulkan dampak nasional dan internasional. ${ }^{1}$ Indonesia menganur prinsip desentralisasi dan otonomi luas, artinya daerah diberikan kewenangan yang luas untuk mengatur dan mengurus urusan pemerintahan yang menjadi kepentingan masyarakat daerah kecuali, urusan pertahanan, urusan keamanan, urusan politik luar negeri, urusan moneter dan fiscal nasional, urusan yustisi, urusan agama.

Pelaksanaan otonomi merupakan perwujudan dari semangat Pasal 18 Undang Undang Dasar Negara Republik Indonesia 1945 (UUD NRI 1945). Menurut Bagir Manan, otonomi merupakan pengakuan atas kebebasan daerah untuk berprakarsa mengatur dan mengurus urusan pemerintahan sesuai dengan tata cara dan pem-

BAPPENAS, 2006, Penyelenggaran Pemerintahan dan Pembangunan Daerah, J akarta: BAPPENAS, hlm. 12-13. batasan yang ditentukan oleh undang-undang. Otonomi mengandung pengertian kemandirian (zelfstandigheid) untuk mengatur dan mengurus sendi-ri sebagian urusan pemerintahan yang diserahkan atau dibiarkan sebagai urusan rumah tangga satuan pemerintahan yang lebih rendah. Berdasarkan hal tersebut, esensi otonomi adalah kemandirian, yaitu kebebasan untuk berinisiatif dan bertanggung jawab sendiri mengatur dan mengurus pemerintahan yang menjadi urusan rumah tangganya. ${ }^{2}$ Dalam rangka agar Pemerintah daerah mampu melaksanakan otonominya secara maksimal sebagai instrumen demokratisasi dan kesejahteraan di tingkat lokal, maka ada 7 elemen dasar yang membentuk pemerintah daerah sebagai suatu entitas pemerintahan, yaitu urusan pemerintahan, kelembagaan, keuangan daerah, perwakilan daerah, pelayanan publik dan pengawasan.

Ketentuan Pasal 1 angka 5 Undang-undang No. 32 Tahun 2004, menyebutkan otonomi daerah adalah hak, wewenang dan kewajiban daerah otonom untuk mengatur dan mengurus sendiri urusan pemerintahan dan kepentingan masyarakat setempat sesuai dengan peraturan perundangan. Dalam penjelasan atas UU No. 32 Tahun 2004 butir 6 ditegaskan prinsip otonomi daerah menggunakan prinsip otonomi yang seluas luasnya dalam arti daerah diberikan kewenangan mengurus dan mengatur urusan pemerintahan diluar yang menjadi urusan Pemerintahan yang ditetapkan dalam undang-undang ini. Daerah memiliki kewenangan membuat kebijakan daerah untuk memberi pelayanan, peningkatan peran serta, prakarsa dan pemberdayaan masyarakat yang bertujuan pada peningkatan kesejahteraan rakyat dan dilaksanakan secara bertanggungjawab. Daerah dapat membuat perjanjian bahkan kerjasama luar negeri untuk memajukan daerahnya sendiri. ${ }^{3}$ Kewenangan Pemerintah (daerah) membuat perjanjian sesuai dengan prinsip kebebasan berkontrak. ${ }^{4}$

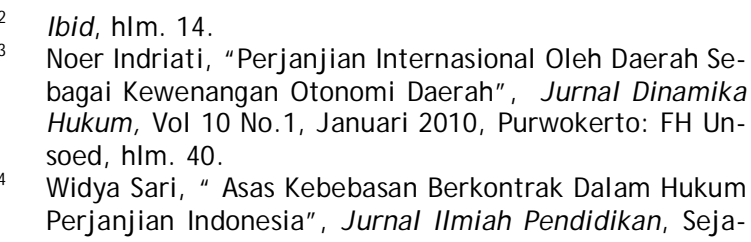
bagai Kewenangan Otonomi Daerah", J urnal Dinamika Hukum, Vol 10 No.1, Januari 2010, Purwokerto: FH Unsoed, hlm. 40.

4 Widya Sari, " Asas Kebebasan Berkontrak Dalam Hukum Perjanjian Indonesia", J urnal IImiah Pendidikan, Seja- 
Kemampuan pemerintah untuk membangunan daerah dengan mempergunakan sumber keuangan tersebut sangatlah terbatas, untuk itulah diperlukan upaya pemerintah daerah melaksanakan fungsinya dengan efektif dan efisien mencari sumber-sumber pendanaan melalui kerjasama dengan pihak ketiga. Berdasarkan berbagai pandangan di atas maka tersimpul bahwa tanpa adanya biaya yang cukup tidak mungkin suatu daerah dapat menyelenggarakan tugas, kewajiban serta kewenangan yang ada padanya dalam mengatur dan mengurus rumah tangganya secara lebih maksimal.

Sebagai solusi mengatasi kesulitan tersebut, maka pada ketentuan Pasal 195 UU No. 32 Tahun 2004 ditetapkan sebagai berikut:

a. Dalam rangka peningkatan kesejahteraan rakyat, daerah dapat mengadakan kerjasama dengan daerah lain yang didasarkan pada pertimbangan efisiensi dan efektivitas pelayanan publik, sinergi dan saling menguntungkan;

b. Kerjasama sebagaimana dimaksud pada ayat (1) dapat diwujudkan dalam bentuk badan kerjasama antar daerah yang diatur dengan keputusan bersama

c. Dalam penyediaan pelayanan publik, daerah dapat bekerjasama dengan pihak ketiga.

d. Kerjasama sebagimana dimaksud pada ayat (1) dan ayat (3) yang membebani masyarakat dan daerah harus mendapatkan persetujuan DPRD.

Keterlibatan pemerintah dalam bidang ekonomi dengan membuat pejanjian atau kontrak bisnis tidak lepas dari tujuan pemerintah untuk memperkuat negara dengan jalan akumulasi kekayaan atau kapital, oleh sebab itu pembangunan ekonomi harus diprioritaskan terutama dengan membangun sarana prasarana untuk pelayanan publik (infrastruktur publik). Istilah ini umumnya merujuk kepada hal infrastruktur teknis atau fisik yang mendukung jaringan struktur seperti fasilitas antara lain dapat berupa jalan, kereta api, air bersih, bandara,

rah dan Sosial Budaya, Vol. 10, No. 3, Januari 2009, hlm. 232-247. kanal, waduk, tanggul, pengelolahan limbah, perlistrikan, telekomunikasi, pelabuhan secara fungsional, infrastruktur selain fasilitasi akan tetapi dapat pula mendukung kelancaran aktivitas ekonomi masyarakat, distribusi aliran produksi barang dan jasa sebagai contoh bahwa jalan dapat melancarkan transportasi pengiriman bahan baku sampai ke pabrik kemudian untuk distribusi ke pasar hingga sampai kepada masyarakat. Dalam beberapa pengertian, istilah infrastruktur termasuk pula infrastruktur sosial kebutuhan dasar seperti antara lain termasuk sekolah dan rumah sakit. ${ }^{5}$

Berdasarkan amanat undang-undang di atas, maka terlihat bahwa format hukum yang di-amanatkan secara normatif bagi pemerintah daerah adalah perjanjian kemitraan dengan pihak ketiga. Dalam prakteknya pemerintah daerah kerapkali membuat perjanjian perjanjian dengan pihak ketiga dalam bentuk build and transfer (BT), desain bangun (design build) atau full finance sharing. ${ }^{6}$

Definisi tentang build and ransfer dalam literatur hukum perdata tidak dijumpai secara tegas. Build and transfer yang merupakan sistem pembiayaan dapat dipergunakan dalam proses pengembangan infrastruktur sektor swasta atau yang disebut dengan sistem pengembangan infrastruktur. Dalam makalah yang disampaikan dalam National Planing Commision Nepal, Singa Durbar menjelaskan bahwa

"Any one of the following systems (here after called Infrastructure Development system) can be adopted in the process of infrastructure development from the private sector :

a. Build, operate and transfer ;

b. Build own and operate;

c. Build own, operateand transfer ;

d. Build, own, operate and sell;

e. Build ,Transfer and operate;

f. Lease in develop and operate ;

Sullivan Arthur, "Economics: Principles in action", Journal Economic, Upper Saddle River: New Jersey Pearson Prentice Hall., August, 2003, hlm. 474.

6 Mahmudi, "Kemitraan Pemeritah Daerah Dan Efektifitas Pelayanan Publik", Jurnal Sinergi-Kajian Bisnis dan Menejemen, Vol.9 No.1, J anuari 2007, hlm 56 
g. Rehabilitate, operate and Transfers." ${ }^{7}$

Build and transfer atau design build adalah bentuk desain bangun antara pemerintah (daerah) dengan swasta untuk melakukan desain dan membangun fasilitas sesuai dengan standar kinerja yang dibutuhkan pemerintah (daerah) dan ketika fasilitas layanan telah jadi, fasilitas itu diserahkan kepada pemerintah dan menjadi milik pemerintah.

Build and transfer dan lembaga lainnya seperti build operate and transfer ${ }^{8}$ merupakan fasilitas swasta resmi yang pertama kali diterapkan di Turki pada tahun 1984 sebagai bagian dari program privatisasi dalam pengembangan infrastruktur untuk negara-negara Asia, privatisasi tersebut menjelma dalam bentuk keterlibatan swasta yang melayani kontrak dengan pemerintah. Hal teresebut terungkap dalam The Role of Build Operate Transfer in Promoting RES project, sebagai berikut :

At the some time, Asia was experiencing an economic boom that opened the doors for new forms of project delivery, based on the principle of privatization. Ernis and Pham (1994) refer to privatization as a process in which the delivery of goods and services, usually administered by the government, is shifted to the private sector. Privatization can be divided in to primarily three areas: the selling of governmental holding, the subcontracting of government services to private undertakers, and the subcontracting of financing and developing publict facilities. ${ }^{9}$

Kontrak atau perjanjian yang dibuat oleh pemerintah daerah dengan pihak swasta dengan sistem build and tranfer, dimana pihak swasta menyediakan sejumlah dana untuk membangun suatu proyek infrastruktur berupa sarana prasa-

Singa Durbar, 2000, National Planing Commision, Kathmandu, hlm. 1.

8 Nyoman Marta J aya, "Analisis Perbandingan Kerjasama Proyek Antara Sistem BOT dan Turn Key (Studi Kasus Pro-yek Multi Investmen PT.Pesero Pos Indonesia), J urnal IImiah Tehnik Sipil, Vol.12, No.01, Januari 2008, hlm. 14.

9 Europen Comission (Directorate General for Energy and Transport) Contract No. NNE52002/52: OPET CHP/DH cluster: The role of Build Operate Transfer in Promoting RES project, Desember 2003, hlm. 16. rana umum dengan biaya yang relatif besar yang tidak mampu dibiayai oleh pemerintah daerah, sehingga pemerintah daerah memberikan kesempatan kepada pihak swasta untuk membangunnya dengan nilai atau harga yang disepakati dan setelah bangunnya selesai, maka pihak swasta menyerahkan bangunan tersebut kepada pemerintah daerah dan kemudian pemerintah daerah akan membayar secara mencicil nilai atau harga bangunan tersebut menurut kesepakatan. Keterlibatan pihak swasta tentunya didasarkan untuk keinginan mencari keuntungan dengan menghindari resiko yang besar dan tanggung jawab yang berlebihan, sehingga pihak swasta cenderung menerapkan prinsip kehati-hatian dalam melakukan kerjasama dengan pemerintah (yang seluruh modalnya dari swasta), serta adanya pendeapat kewajaran tentang bisnis tersebut. ${ }^{10}$

Beberapa persoalan hukum kontrak terutama build and transfer yang menjadi kajian ini semakin terlihat adanya penomena hukum yang menyelimuti aspek hukum dari build and transfer, yaitu adanya suatu kekaburan hukum dan kekosongan norma, ${ }^{11}$ karena berbagai aspek yang mengatur build and transfer belum diatur secara khusus, akibatnya praktik praktik kemitraan dan perjanjian yang dilakukan oleh pemerintah (daerah) dalam membuat perjanjian build and transfer cenderung menimbulkan persoalan hukum. Fenomena hukum di Indonesia yang masih tertinggal, bukan saja pada sektor perjanjian (kontrak), bahkan pada sektor lainnya pun memerlukan pembaruan. A Endeshaw menyatakan:

"The persisting ignorance of developing countries, including Indonesia policy makers and so called experts in Indonesia that the forms and scope of IP need to

10 Maryann Waryhas, "It Looks Like a Good Deal- But Is It a Fair Deal ", The J ournal Publication of Stout Risius Ross, Fall 2005, SRR, hlm 2; Lyman PQ Jhonson, "Corporate Officer and Business J ugmen Rule", J ournal The Business Lawyer, Vol. 60, February 2005, Washington and Lee University, hlm 119; Tambosso P.Eng , "Fairness Opinion- Why- or Why Not", J ournal Dailly, April, 2008, hlm. 15.

11 Lalu Hadi Adha, "Kontrak Build Operate Transfer Sebagai Perjanjian Kebijakan Pemerintah Dengan Pihak Swasta", Jurnal Dinamika Hukum, Vol.11 No.3. September 2011, Purwokerto: FH Unsoed, hlm. 536. 
be congruent with the level and type of cultural, social economic and technological substructure within a society has left them prey to transplant of law and rules that meet the requirements of the most industrially developed nations." ${ }^{12}$

Menurut Yudi Kristiana, kehadiran hukum bukan untuk dirinya sendiri, melainkan untuk sesuatu yang lebih luas, untuk itulah jika terjadi permasalahan dalam hukum maka hukumlah yang harus diperbaiki. ${ }^{13}$

Berdasarkan persoalan hukum di atas, maka penelitian ini menjadi penting untuk mengkaji bagaimana hukum di Indonesia mengatur tentang perkembangan kontrak build and transfer dan bagaimana praktek build and transfer itu dilakukan oleh pemerintah daerah. Hasil penelitian ini tentunya akan sangat bermanfaat baik secara teoritis bagi pengembangan ilmu hukum kontrak dan secara praktis dapat menjadi masukan bagi pemerintah dalam menyusun peraturan hukum yang sesuai dengan perkembangan masyarakat.

\section{Permasalahan}

Berdasarkan atas pemahaman dan pokok pikiran yang tersirat dalam pendahuluan, maka ada dua permasalahan yang akan dibahas pada artikel ini. Pertama, mengenai pengaturan hukum perjanjian antara pemerintah daerah dengan pihak swasta terutama build and transfers; dan kedua mengenai konsep build and transfer dan penerapannya di dalam praktik di Nusa Tenggara Barat.

\section{Metode Penelitian}

Penelitian hukum (legal research) Ini dilakukan sesuai dengan kekhasan yang dimiliki oleh ilmu hukum (jurisprudence) yang tentunya berbeda dengan ilmu sosial (social science) dan ilmu alam (natural science). Metode penelitian hukum mempunyai ciri yang khusus penggalian

12 A.Endeshaw, "Intellectual Property and the WIPO Development Agenda", J ournal of Information Law and Technology, Special Issue, No,1, J une, 2007, hlm. 15; "” ( Dr.)

13 Yudi Kristiana, "Ketika Hukum Tidak lagi Otentik", J urnal Supremasi Hukum, Jakarta: Universitas Sahid, Vol IV No.1, Oct-Maret 2011, hlm. 7. bahan hukum (legal materials) dan analisa kritis (critical analysys) terhadap bahan hukum dengan melakukan penelusuran (explorative), pengkajian mendalam (inquiry) dan penafsiran (interpretation)). Dalam melakukan penelitian ini disamping menggunakan metode normatif juga akan dilakukan pendekatan kasus. Oleh sebab itu, di samping mengumpulkan bahan hukum berupa beberapa peraturan baik undang undang sampai peraturan daerah, juga dikumpulkan beberapa bahan dokumen kontrak yang terkait dengan objek penelitian di NTB.

\section{Pembahasan \\ Konsep Kerjasama Build and Transfer antara Pemerintah Daerah dengan Pihak Swasta}

Secara teoritis ada beberapa model pelayanan yang dilakukan oleh pemerintah. ${ }^{14}$ Pertama, governance service di mana pemerintah memberikan semua jenis pelayanan publik kepada masyarakat. Pemerintah menjalankan fungsi sebagai pengatur pelayanan (service arranger) dan produsen pelayanan (service producer); kedua, intergogovernmental agreement, dimana pemerintah pusat dapat mendelegasikan kewenangan kepada pemerintah daerah untuk memberikan pelayanan. Dalam model ini konsumen membayar secara langsung biaya pelayanan kepada pemerintah daerah atau yang menjalankan fungsi provisi, sedangkan fungsi produksinya tetap berada pada pemerintah pusat; ketiga, government vending, dalam hal ini konsumen (individu/ organisasi) bertindak sebagai pengatur (service arranger) dan membayar kepada pemerintah atas sejumlah pelayanan publik, misalnya seorang individu dapat menggunakan tenaga polisi untuk mengontrol (mengawasi) penonton dalam pertandingan olah raga yang dimiliki secara pribadi; keempat, contract, dimana pemerintah dapat mengontrak atau memberikan mandat kepada perusahaan negara (perusahaan daerah) untuk memberikan pelayanan. Pihak yang dikontrak adalah perusahaan swasta, misalnya pemerintah mengontrak perusahaan swasta untuk penyapuan jalan, pemeliharaan lampu jalan, pemeliharaan traffic

14 Nurdjaman Arsyad, 1992, Keuangan Negara, Jakarta: Intermedia, hlm. 38 
light dan lain lain, konsumen membayar secara langsung biaya pelayanan yang diterima kepada produsen; keempat, grand, pemerintah memberikan subsidi kepada produsen dengan tujuan menurunkan harga barang dan jasa pelayanan, misalnya pemerintah memberikan penurunan nilai pajak kepada produsen agar nilai barang yang akan dibeli oleh konsumen akan murah; kelima, voucher artinya konsumsi barang tertentu diarahkan pada konsumen tertentu, perusahaan memberikan pelayanan dibayar secara langsung oleh pemerintah; keenam, franchise dimana pemerintah memberikan hak monopoli kepada suatu perusahaan swasta untuk memberikan pelayanan dalam suatu batas geografis tertentu dan pemerintah memberi tarif yang harus dibayar oleh konsumen. Dalam kasus ini pemerintah melakukan fungsi sebagai pengatur perusahaan swasta, sedangkan konsumen membayar secara langsung kepada perusahaan swasta itu; ketujuh, market, yaitu suatu sistem dimana kon-sumen memilih produsen barang dan jasa yang dikehendaki sesuai dengan kualitasnya tanpa campur tangan pemerintah. Pemerintah sama sekali tidak berperan baik sebagai penyedia jasa maupun sebagai pengatur pelayanan jasa (services arranger), semuanya tergantung pada konsumen dan produsen; kedelapan, voluntary service, yaitu suatu sistem dimana lembaga swada-ya secara sukarela memberikan pelayanan yang dibutuhkan masyarakat. Lembaga swadaya tersebut bertindak sebagai pengatur (service arranger) dan penyedia jasa (service producer); kesembilan, self service yaitu dimana penyediaan pelayanan dilakukan sendiri oleh individu/ masyarakat;

Model pelayanan publik di atas merupakan ilustrasi aktivitas penyediaan pelayanan publik yang biasa dilakukan di Amerika. Model pelayanan publik di Indonesia telah muncul berbagai pola alternative pemenuhan pelayanan publik dengan melibatkan sektor swasta yaitu build ope-rate and transfer (BOT), build operate and own (BOO) dan sebagainya. ${ }^{15}$ Tiga model interaksi kerjasama antara pemerintah, swasta dan

15 Lalu Hadi Adha, "Kontrak BOT Sebagai Perjanjian Kebijakan (Beleid Overeenskomst)", J urnal Law Reform, Vol. 4 No. 1, 2009, hlm 1. masyarakat, adalah sebagai berikut. ${ }^{16}$ Pertama, model classical public adminstration, yang memberikan perhatian bagaimana pemerintah melakukan tindakan administrasi secara demokrasi, efisien, efektif dan bebas dari manipulasi kekuasaan, serta bagaimana pemerintah dapat beroerasi secara tepat, cepat dan berhasil; kedua, model menejemen publik baru (new public managemen), yaitu suatu model bagaimana mentrasformasikan manajemen sektor swasta ke dalam organisasi publik serta mengembangkan inisiatif pengaturan sistem seperti deregulasi, privatisasi dan kontrak menejemen; model new public manajemen ini berkembang menjadi beberapa model, yaitu: (a) efficeincy drive yaitu model yang menekankan pentingnya efisiensi dengan menekankan betapa pentingnya sector public berperilaku seperti swasta, sehingga usaha ke arah itu harus dilakukan dengan cara meningkatkan pengawasan menejemen keuangan, penghematan atau efisiensi, penguatan fungsi penganggaran, penciptaan sistem informasi. Model ini terkait dengan gaya ekonomi politik Margaret Tactcher yang anti dan mengeliminasi pemborosan dan pemerintahan yang birokratis. (b) Down sizing yaitu model yang memperkecil lingkup sektor publik dengan menciptakan fleksibelitas organisasi, mengembangkan pola pelayanan yang fleksibel dan variatif, memperkuat desentralisasi tanggung jawab kegiatan dan anggaran ke tingkat bawah. Model ini akan memberikan perhatian terhadap pentingnya jaringan kerja (network) dengan organsasi lain diluar pemerintah, pentingnya pembentukan aliansi strategis dengan badan badan lain diluar pemerintah sebagai bentuk baru kordinasi yang lebih luas. (c) In search of excellence, yaitu model yang menekankan pentingnya pengaruh nilai, budaya, ritus dan simbol yang dapat mempengaruhi perilaku individu dalam bekerja. Model ini memilik 2 (dua) pendekatan utama yaitu pendekatan bottom-up dan pendekatan top down. Pendekatan bottom-up memberikan penekanan pada

16 Antonius Tarigan, "Tranformasi Model New Governance Sebagai Kunci Menuju Optimalisasi Pelayanan Publik di Indonesia", J urnal Usahawan, No.02 Th XXXII, Februari 2003, hlm. 31. 
pengembangan organisasi sebagai organisasi pembelajaran (learning organitation). Sedangkan top-down menekankan upaya upaya untuk memperlancar perubahan budaya organisasi, proyeksi visi secara top down dan kepemimpinan secara kharismatik dan menekankan pada penekanan fungsi menejemen sumber daya manusia. (d) Public service oriented suatu model merefleksikan penyelarasan ide-ide dalam manaj emen sektor swasta ke dalam manaj emen sektor publik, serta penguatan kembali peran manajer sektor publik dengan menerapkan manajemen yang berkualitis tinggi secara lebih meyakinkan yang sebelumnya telah dirusak oleh berbagai malpraktik dan patologi. Karakter model ini adalah memberikan pelayanan yang berkualitas tinggi (prima), proses manajemen yang lebih merefleksikan kepentingan pengguna (user) lebih dari sekedar kepentingan konsumen, penekanan pada pembelajaran masyarakat daripada sekedar penyediaan pelayanan rutin, serta menjamin partisipasi masyarakat dan prinsip akuntabilitas.

Beberapa gagasan di atas memiliki visioner yang baik dalam perbaikan pelayanan publik, tetapi upaya untuk menerapkan dan mengadopsi model dan gagasan di atas ternyata masih diragukan. Keraguan itu muncul diakibatkan oleh beberapa pertanyaan yaitu sejauhmana prinsip prinsip manajemen sektor swasta dapat diterapkan ke dalam manajemen sektor publik dan bagaimana menggeser peran dan logika pemerintah, serta mengembangkan hubungan kerja baru antara pemerintah, swasta dan masyarakat dalam kultur yang lebih egaliter dan partisipatif. Pertanyaan pertama muncul karena pada dasarnya terdapat perbedaan karakter antara sektor swasta dan pemerintah. Perbedaan itu berkaitan dengan pilihan publik (public choice), kepentingan publik (public interest), pemilikan publik (public ownership) dan kebutuhan kolektif dan keadilan.

Ada pendapat yang sangat umum, bahwa peran pemerintah seyogyanya hanya dibatasi pada masalah masalah yang tidak bisa ditangani swasta dan masyarakat seperti masalah pertahanan dan keamananm, penegakan hukum dan hubungan luar negeri. Penyelenggaraan penye- diaan pelayanan yang bersifat toll goods dapat diserahkan kepada swasta dan masyarakat. Dalam kondisi ini pemerintah akan lebih berperan sebagai regulator atau fasilitator dan bukan sebagai produser.

Berdasarkan gambaran di atas, tampak masih ada keraguan antara sikap pemerintah yang ingin melepaskan persoalan penyediaan sarana publik kepada swasta dengan keinginan peme-rintah untuk mengatur secara lebih mendalam tentang sistem pengadaan infrastruktur pulik tersebut. Keraguan itulah yang kemudian memunculkan model lain yang disebut new governance.

Ketiga, model new governance, ${ }^{17}$ suatu model dimana penyelenggaraan pemerintahan dibangun berdasarkan pola interaksi baru antara pemerintah dan masyarakat untuk mengembangkan dan menyediakan kebijakan dan pelayanan publik. Pada model manajemen publik baru menekankan ide pembaruan peran pemerintah secara incremental melalui peningkatan efisiensi ma-najemen sektor publik yang mengandalkan pola hubungan kerja antar organisasi di dalam, sedangkan pada new governance menekankan ide pembaruan proses pemerintah secara transformatif melalui peningkatan kapasitas pemerintah dan sistem pengaturan yang mengandalkan pola hubungan kerja dan interaksi antara organisasi pemerintah, swasta dan masyarakat secara kooperatif atau kemitraan.

Sistem pengaturan hukum kontrak dapat dibedakan menjadi dua macam yaitu closed system dan open system. Sistem tertutup (closed system) menentukan bahwa setiap orang tidak diperkenankan untuk mengadakan hak hak kebendaan baru selain yang sudah diatur dalam undang-undang. Sistem terbuka (open system) adalah setiap orang bebas untuk mengadakan perjanjian baik yang sudah diatur maupun belum diatur dalam undang undang sebagaimana diatur dalam Pasal 1338 ayat (1) KUH Perdata yang mengatur bahwa semua perjanjian yang dibuat secara sah berlaku sebagai undang undang bagi mereka yang membuatnya. Lahirnya perjanjian baru build and transfer,

$17 \quad$ Ibid, hlm. 32. 
yang belum dikenal dalam Kitab Undang-undang Hukum Perdata atau disebut dengan perjanjian innominaat, merupakan konsekwensi logis dari dianutnya sistem terbuka (open system) dalam sistem hukum kontrak di Indonesia.

Build and Transfer adalah suatu perjanjian dimana kedudukan kontraktor hanya membangun proyek tersebut, setelah selesai dibangunnya proyek tersebut maka proyek yang bersangkutan di-serahkan kembali kepada pihak bouwheer tanpa hak kontraktor untuk mengelola/memungut hasil atau revenue dari proyek tersebut. Sebaliknya sebagai imbalan untuk membangun proyek tersebut, pihak bouwheer memberikan imbalan tertentu sesuai dengan kesepakatan dan bisa dihitung dengan cost plus fee atau secara lumsum, sehingga build and transfer dalam praktek disebut dan dipadankan dengan kontrak design and build atau dalam kontrak yang dibuat oleh Pemerintah Daerah di NTB disebut full finance sharing. Selain itu, itu dikenal pula istilah turn key project sebagai padanan dari build and tranfer yaitu untuk menyamakannya dengan pemborongan biasa namun dengan sistem pambayaran dalam jangka waktu yang lebih panjang dari pemborongan biasa.

Ciri kontrak design and build (DB) atau build and transfer adalah sebagai berikut. Pertama, syarat terhadap bangunan (proyek) yang akan dibangun ditetapkan oleh bouwheer, selanjutnya berdasarkan persyaratan tersebut maka pihak kontraktor akan menyusun suatu contractor's proposal yang didalamnya sudah termasuk fabrikasi dan design proyek. Dalam penyusunan desain proyek tersebut cenderung terjadi negosiasi antara bouwheer dengan kontraktor mengenai hal hal yang menyangkut proyek. Kedua, harga kontrak diajukan penawaran oleh Kontraktor dan kemudiaan dilakukan negosiasi untuk mencapai harga proyek yang disepakati bersama. Negosiasi tersebut mencakup resiko atas kenaikan harga harga bahan bangunan dikemudian hari menjadi tanggung jawab kontraktor. Ketiga, Peranan para professional sangat kecil atau tidak banyak para pihak yang terlibat, misalnya keterlibatan pihak konsultan independen, arsitek dan lain lain, karena se- muanya sudah menjadi kesatuan dalam kontraktor.

Berdasarkan ciri build and transfer atau kontak design and build, maka terlihat beberapa kelebihan dan kekurangan dalam sistem BT dibandingkan dengan kontrak pemborongan yang konesional. Tanggung jawab hukum pihak kontraktor bersifat single point responsibility dimana tang-gung jawab kontraktor bersifat keseluruhan. Tentu saja tanggung jawab seperti itu akan sangat memudahkan dan memuaskan bagi pihak bouw-heer (pemilik proyek). Penerapan prisip tanggung jawab seperti itu mengakibatkan bouwheer tidak lagi menyandarkan diri pada pendapat luar, misalnya tidak ada lagi dibedakan kesalahan yang disebabkan design fault, workmanship fault, manufacturing fault, atau assembly fault. Semua kesalahan menjadi tanggung jawab kontraktor tanpa dipisah pisahkan dan hal ini akan menghemat dalam penyelesaian. Begitu besar tanggung jawab kontraktor secara tunggal (single liability), maka hal tersebut dapat menjadi pendorong bagi kontraktor untuk bekerja lebih bertanggung jawab terhadap ketepatan waktunya. Waktu pelaksanaan proyek akan lebih cepat dan lebih efisien karena komunikasi antara bouwheer dengan kontraktor berjalan lebih intensif

Namun demikian, secara teoritis dijumpai pula beberapa kelemahan dengan sistem build and transfer atau design and build. Pertama, pihak kontraktor harus mendesain atau bertanggung jawab untuk mendesain suatu proyek, sehingga menyebabkan usaha untuk mendesain biasanya tidak dilakukan secara maksimal. Bisa jadi adanya kekurangan pengalaman untuk mendesain atau prioritas utama bukan ditempatkan soal desainn tetapi pada soal fabrikasi. Artinya, apabila ada unsur aestetika bertentangan dengan unsur fabrikasi, maka unsur fabrikasi lebih dimenangkan dan unsur keindahan dikalahkan; kedua, kualitas pekerjaan menjadi kurang terjamin, karena dengan sistem ini tanggung jawab pekerjaan bersifat tunggal maka ada kecendrungan pihak kontraktor mengerjakan sendiri seluruh pekerjaan tanpa mau menyewa atau membayar tenaga tenaga profesional yang lebih mampu untuk mendisgn, me- 
rancang dan mengawasi pekerjaan oleh tenaga arsitek dan konsultan.

Pada build operate tranfer pihak swasta setelah membangun proyek tersebut kemudian berhak mengelola atau mengoperasikan proyek tersebut dalam waktu tertentu dan dengan pengoperasian tersebut pihak swasta memperoleh keuntungan dan setelah jangka waktu disepakati kemudian proyek tersebut diserahkan kepada pihak swasta tanpa memperoleh pembayaran dari pemerintah, sedangkan dalam build transfer, pihak swasta tidak memiliki kesempatan untuk mengopersaikan proyek yang dibangunnya, karena langsung diserahkan kepada pemerintah dan pemerintah selanjutnya akan membayar harga pembangunan proyek tersebut secara mencicil. Pilihan pemerintah (daerah) melakukan pola kerjasama build and transfer karena perjanjian dengan model build operate and transfer ternyata secara ekonomis tidak menguntungkan, sebab apabila bangunan itu diserahkan dalam jangka waktu 30 tahun, maka nilai dan manfaat bangunan telah berkurang. ${ }^{18}$

Tindakan Pemerintah Pusat ataupun Pemerintah Daerah yang melakukan perjanjian atau kontrak dengan pihak ketiga merupakan bentuk kemitraan daerah. Bentuk kemitraan daerah tersebut untuk masing masing daerah dikelompokan dalam berbagai bentuk. Kabupaten Mataram NTB, misalnya membedakan kemitraan itu antara lain: penyertaan modal daerah pada pihak ketiga, pembelian surat berharga, pendirian Perseroan Terbatas (PT) dan kerjasama dengan pihak ketiga. Peraturan Daerah Kota Mataram No. 4 Tahun 2004 tentang Pedoman Kerjasama Daerah, Pasal 7 mengelompokkan kontrak bangun, kelola, sewa, serah/build, operate, leassehold, and transfer sebagai bentuk kerjasama dengan pihak ketiga. Bandingkan dengan Peraturan Daerah Kota Subang No. 10 Tahun 2001 tentang Kerjasama Daerah dengan Pihak Ketiga, membagi 3 (tiga) kelompok

18 Hari Nugraha Nurjaman, "Analisis Perbandingan Kemitraan build operate transfer (BOT) dan Konsesi Pada Pembiayaa Pada Pembangunan Boulevars Jodoh dan Rumah Susun Sewa Kota Batam", Jurnal Rekayasa Dan Menejemen Pembiayaan Perumahan, J akarta: Universitas Persada Indonesia YAl, Vol.1 No.1, Tahun 2008, hIm. 37. kerjasama yaitu: pembelian saham, pembentukan perseroan terbatas dan kerjasama dalam bentuk kontrak.

Berlakunya Perpres No.13 Tahun 2010 tentang Perubahan Peraturan Presiden No. 65 Tahun 2007 tentang Kerjasama Pemerintah dengan Badan Usaha Dalam Penyediaan Infrastruktur tergambar lebih terinci para pihak (subjek hukum) dalam kerjasama antara pemerintah dengan swasta. Para pihak tersebut adalah: pertama, Badan Usaha yaitu badan hukum Indonesia yang dimiliki oleh sponsor dan yang akan menanda tangani Perjanjian Kerjasama (Coopration Agreement) dengan pemerintah; kedua, Bank Bank Komersial, baik bank lokal maupun asing yang menyediakan pendanaan bagi kegiatan proyek. Termasuk di dalamnya Bank Pembangunan Asia, Bank Dunia dan afiliasinya (Asosiasi Penjamin Investasi seperti Multilateral Investment Guarantee Association); ketiga, Para sponsor proyek yang merupakan para pemegang saham dari badan usaha yang biasa disebut developers; keempat, Penjamin Infrastruktur yang dikenal sebagai PT. Penjamin Infrastruktur Indonesia (PT. PII) yang didirikan oleh Pemerintah untuk menjamin kewajiban kewajiban pemerintah; kelima, Pihak Ketiga Pemberi J asa yang diikutkan oleh pihak Badan Usaha dalam rangka perencanaan konstruksi dan perawatan (operation and maintenance); keenam, Badan yang Mengeluarkan Perij inan seperti Badan Kordinasi Penanaman Modal (BKPM); ketujuh, Badan Kontrak Pemerintah (Governement Contracting Agency) terdiri dari Kementerian, Pemerintah Propinsi maupun Kabupaten/Kota; kedelapan, Komite Kebijakan Percepatan Penyediaan Infrastruktur (KKPPI) suatu lembaga yang bertugas melakukan koordinasi atas percepatan pembangunan infrastruktur yang diketuai oleh Menko Perekonomian; kesembilan, Unit Pusat Kerjasama Pemerintah dan Swasta (Public Private Partenrship Central Unip atau P3CU) suatu unit di Bappenas yang bertugas memberikan bantuan kepada KKPPI dan Pemerintah dalam menyusun kebijakan, serta menyusun buku panduan daftar proyek yang dapat dikerjasamakan; kesepuluh, Ke- 
menterian Kemuangan memberikan persetujuan atas jaminan pemerintah dan insentif pajak.

\section{Bentuk Infrastruktur Publik yang Dikerjasa- makan}

Peraturan perundangan di Indonesia tidak dijumpai pengertian infrastruktur, tetapi dipergunakan istilah fasilitas umum atau untuk kepentingan umum. Dalam konteks pembangunan yang mempergunakan pola build operate and transfer (BOT) dan build and transfer, maka Gerald I Katz menyebutkan antara lain: jalan raya, pengelolaan limbah/sampah dan tenaga listrik, perkeretaapian. ${ }^{19}$ Donald Hagman, meskipun tidak menjelaskan makna public use, tetapi memberikan contoh yang disebut public use seperti city parking, fire engine house, highway-roadways, airport, side-walk, sewers, local streets-major roads, schools. Dikategorikan public use, apabila ditujukan untuk publik (public purposes), membawa manfaat bagi publik (public benefit) atau membawakan kemakmuran publik (public welfare) dan meskipun Donald Hagman sudah memberikan petunjuk untuk dapat disebut sebagai public use rupanya Donald Hagman tidak merumuskan public use secara memadai, akhirnya dikatakan what constitutes a public use is ultimately a judicial question. The term is an elastic one in order to keep abreast of changing social condition. ${ }^{20}$ Anthony J. Catanese (et.al) meskipun tidak memberikan perumusan makna public utility, namun memberikan beberapa contoh jenis pembangunan yang masuk dalam public utility yakni jalan raya, kereta api, saluran air, kantor pemerintah, parkir umum yang disediakan oleh pemerintah dengan peraturan pemerintah. Konsep public utility berkembang di Amerika Serikat dan Canada yang kemudian diperluas cakupannya dengan penambahaan aktivitas lokal seperti listrik, gas, telepon, transit yang

19 Geral I Karz and Stephen W Smith, "Build Operate Transfer, The Future of Public Construction", J ournal of Construction Accounting and Taxation, March/ April 2003, hlm. 47.

20 Donald G Hagman, "Public Planning and Control of Urban and Development", Cases and Material Journal, No.2 West Publishing, 2008, hlm. 68. menurut Encyclopaedia of thesocial sciences, ${ }^{21}$ yaitu:

The term public ultilitiesis commonly used to designate industries whoses services, particularly in supplying electricity, gas, water, telephone, street railway and bus transportation, operate chiefly whitin municipal areas, under municipal permits or franchises. In a broader sense, both practical and theoretical, the trem has come increasingly to include railroads, telegraph and other enterprises to which special public interest may be ascribed. Covering some of the must important and must heavily capitalized industries, the public utility concept also involves some of the must fundamental theoretical aspect of the modern economic system.

Rumusan social interest atau kepentingan umum yang selama ini masih kabur pengaturannya dalam berbagai peraturan akhirnya dapat ter-pecahkan setelah pemerintah mengeluarkan Peraturan Presiden No. 13 Tahun 2010 tentang Perubahan Perpres No. 65 Tahun 2007. Dalam Perpres ini telah diatur beberapa infrastruktur yang boleh dikerjasamakan. Pertama, infrastruktur transportasi, meliputi pelayanan jasa kebandarudaraan, penyediaan dan/ atau pelayanan jasa kepelabuhanan, sarana dan prasarana perkeretaapian; kedua, infrastruktur jalan, meliputi jalan tol dan jembatan tol; ketiga, infrastruktur pengairan, meliputi saluran pembawa air baku; infrastruktur air minum yang meliputi bangunan pengambilan air baku, jaringan transmisi, jaringan distribusi, instalasi pengolahan air minum; keempat, infrastruktur air limbah yang meliputi instalasi pengolah air limbah, jaringan pengumpul dan jaringan utama, dan sarana persampahan yang meliputi pengangkut dan tempat pembuangan; kelima, infrastruktur telekomunikasi dan informatika, meliputi jaringan telekomunikasi dan infrastruktur e-government; keenam, infrastruktur ketenagalistrikan, meliputi pembangkit, termasuk pengembangan tenaga listrik yang berasal

21 Edwin R.A. Seligman, 2005, Encyclopaedia of the social sciences, vol. 11, New York: the Macmillan, hlm. 674675. 
dari panas bumi, transmisi, atau distribusi tenaga listrik; dan ketujuh, infrastruktur minyak dan gas bumi, meliputi transmisi dan/atau distribusi minyak dan gas bumi.

\section{Landasan Hukum Perjanjian Build and Trans- fer di Indonesia}

Perjanjian kerjasama kemitraan antara Pemerintah (Daerah) dengan Pihak Swasta telah mendapat pengaturan di berbagai peraturan perundang-undangan di Indonesia. UU No. 32 Tahun 2004 tentang Pemerintahan Daerah memberikan wewenang kepada pemerintah daerah dalam hal ini Gubernur/Bupati/Walikota untuk menjalin kerjasama dengan pihak ketiga untuk membangun infrastruktur publik didaerah (Pasal 195 ayat (3) dan (4). Dalam penyediaan pelayanan publik, daerah dapat bekerjasama dengan pihak ketiga. Ketentuan tersebut, pernah diatur dalam Pasal 87 ayat (3) dan (4), UU No. 22 Tahun 1999, yang menentukan:

(3) Daerah dapat mengadakan kerjasama dengan badan lain yang diatur dengan keputusan berasama ;

(4) Keputusan bersama dan/atau badan kerjasama sebagaimana dimaksud ayat 1 , ayat 2 dan ayat 3 yang membebani masyarakat dan Daerah harus mendapatkan persetujuan DPRD masing masing.

Terdapat perbedaan prinsip antara kedua undang-undang di atas, yaitu UU No. 32 Tahun 2004 hanya membatasi kerjasama daerah dengan pihak ketiga pada kerjasama pembangunan sarana pelayanan publik, sedangkan UU No. 22 Tahun 1999 tidak ada pembatasan bagi Daerah dalam membuat kerjasama dengan pihak ketiga.

Pemerintah Daerah tidak dapat sewenang-wenang membuat kerjasama tanpa memperhatikan batas kewenangan yang berada pada kewenangannya, sehingga diatur pembagian urusan Pemerintahan antara Pemerintah, Pemerintah Daerah Propinsi dan Pemerintah Kabupaten/Kota sebagaimana diatur dalam Peraturan Pemerintah No. 38 Tahun 2007 tentang Pembagian Urusan Pemerintahan antara Pemerintah, Pemerintah Daerah Propinsi dan Peme- rintah Kabupaten/Kota. Pengadaan infrastruktur publik yang menyangkut kepentingan masyarakat seperti rumah sakit (kesehatan), pasar (perdagangan) dan gedung-gedung sekolah (pendidikan) merupakan tanggung jawab pemerintah daerah. Oleh karena itu, potensi pengadaan infrastruktur publik tersebut dapat diadakan dengan menggunakan mekanisme build and transfer (BT), jika pemerintah daerah kesulitan dana untuk mengadakan sendiri fasilitas tersebut.

Pengadaan infrastruktur melalui suatu kerjasama tersebut tentunya memerlukan pengaturan yang lebih khusus. Oleh karena itu, Pemerintah kemudian mengeluarkan Peraturan Pemerintah No. 50 Tahun 2007 tentang Kerjasama Pemerintah dengan Pihak Ketiga. Sebelum keluarnya PP No.50 Tahun 2007 sebenarnya Pemerintah sudah mengeluarkan Peraturan Presiden No. 67 Tahun 2005 tentang Kerjasama Pemerintah dengan Badan Usaha Dalam Penyediaan Infrastruktur yang kemudian diperbaharui dengan Peraturan Presiden No 13 Tahun 2010.

Keputusan Presiden No. 80 Tahun 2003 jo Peraturan Presiden No. 54 Tahun 2010 mengatur tentang Pedoman Pelaksanaan Pengadaan Barang dan Jasa Pemerintah yang berlaku secara umum untuk pengadaan jasa pemborongan yang didasarkan telah tersedianya dana Pemerintah. Dalam Peraturan Presiden No. 67 Tahun 2005 jo Perpres No. 13 Tahun 2010 diatur secara khusus tentang mekanisme pencarian mitra kerjasama yang bisa membantu Pemerintah untuk membangun inftrastruktur publik dalam mana Pemerintah tidak memiliki dana untuk membangun prasarana tersebut. Oleh karena itu, mekanisme pengadaan barang dan jasa atau pengadaan badan usaha yang akan bermitra dengan Pemerintah dapat saja terjadi melalui dua cara yaitu karena adanya inistiatif dari Pihak Swasta dan inisiatif dari Pihak Pemerintah.

Terdapat beberapa tahap yang perlu dilakukan, apabila proyek tersebut merupakan inisiatif berasal dari Pemerintah (solicited), yaitu: pemilihan proyek atau identifikasi proyek oleh GCA, konsultasi publik untuk mendapat masukan dari masyarakat, studi kelayakan yang dila- 
kukan oleh GCA, dukungan Pemerintah untuk memperoleh perijinan dan insntif pajak, pengadaan (Tender), pelaksanaan dan pemantauan, sedangkan apabila proyek tersebut merupakan inisiatif swasta (unsolicited), maka proses pemilihan proyek tahap pertama sampai dengan tahap keempat menjadi tugas swasta dan tahap kelima sampai tahap ketujuh menjadi tugas pemerintah. Dalam hal inisiatif atau prakarsa itu datang dari pihak Swasta (Badan Usaha), maka pihak swasta akan melakukan sendiri proses (Pasal 11 Peraturan Presiden No. 67 Tahun 2005), seperti: studi kelayakan, rencana bentuk kerjasama, rencana pembiayaan proyek dan sumbernya dan rencana penawaran kerjasma yang mencakup jadwal, proses, serta cara penilaian.

Penawaran pihak Swasta tersebut akan dinilai oleh Pemerintah apakah telah sesuai dengan beberapa hal sebagaimana diatur pada Pasal 7 Perpres No. 67 Tahun 2005. Pertama, kesesuaian dengan rencana pembangunan jangka menengah dan rencana strategis sektor infrastruktur; kedua, kesesuaian lokasi proyek dengan Rencana Tata Ruang Wilayah; ketiga, keterkaitan antar sektor infrastruktur dan antar wilayah; dan keempat, analisa biaya dan manfaat. Badan Usaha, apabila telah memenuhi berbagai persyaratan di atas, maka barulah dilanjutkan kepada proses selanjutnya yaitu penandatanganan memorandum of understanding (MOU), permohonan persetujuan dprd dan penandatanganan kerjasama.

Dokumen tawaran kerjasama yang diajukan oleh pihak Badan Usaha tersebut, apabila tidak tercapai kesepakatan lebih lanjut, maka dokumen kajian yang diprakarsai pihak Badan Usaha tersebut akan dilakukan pelelangan umum kepada badan usaha lain yang mungkin bersedia mengerjakan proyek yang sudah dirancang oleh badan usaha pertama tadi, maka badan usaha pemrakarsa berhak memperoleh imbalan atas hak kekayaan Intelektual terhadap rencana bangunan proyek yang telah dirancang. Pihak pemrakarsa, apabila ikut juga dalam proses tender, maka jika pihak pemrakrsa memenangkan tender tersebut, maka kepada pihak pemrakarsa berhak memperoleh tambahan nilai proyek sebesar sepuluh persen dari nilai tender yang dimenangkan oleh Pemrakarsa.

Apabila ditelusuri lebih jauh sebelum dikeluarkannya Peraturan Presiden No. 67 Tahun 2005 J o. Perpres No. 13 Tahun 2010, Pemerintah telah mengantisipasi perlunya peraturan tentang kerjasama daerah dengan pihak swasta dalam pembangunan infrastruktur Keputusan Presiden No. 7 Tahun 1998 tentang Kerjasama Pemerintah dan Badan Usaha Swasta Dalam Pembangunan dan Pengelolaan Infrastruktur. Keputusan Presiden tersebut telah menggariskan beberapa ketentuan yang prinsip tentang kerjasama antara pemerintah dengan badan usaha. Pertama, kerjasama pemerintah dengan badan hukum swasta itu haruslah dengan badan hukum swasta yang berbentuk badan hukum Indonesia; kedua, infrastruktur yang akan dibangun harus benar-benar strategis antara lain: pembangkit tenaga listrik, transmisi dan pendistribusian gas alam, penyaluran dan penyimpanan, distribusi atau, pengelolaan air bersih, pengelolaan air limbah dan sampah, pembangunan jalan tol, jembatan, dermaga dan bandara dan pengadaan sarana pengoperasian sarana telekomunikasi atau infrastruktur lainnya yang ditentukan dengan Keputusan Presiden (Pasal 2 Keputusan Presiden No. 7 Tahun 1998); ketiga, pengikutsertaan badan usaha swasta dalam pembangunan dan pengelolaan infrastruktur harus dilakukan dengan penawaran yang terbuka dan transparan, sehingga mendorong semakin berkembangnya iklim investasi (Pasal $3 \mathrm{Ke}$ putusan Presiden No. 7 Tahun 1998); keempat, rencana pembangunan dan atau pengelolaan infrastruktur tersebut jika merupakan proyek Pemerintah Daerah, maka perjanjian kerjasama tersebut dibuat oleh gubernur kepala daerah atau bupati/ walikota; kelima, perjanjian kerjasama tersebut harus memuat hal-hal, sebagai berikut: lingkup pekerjaan, jangka waktu, tariff pelayanan dalam hal menyangkut pengelolaan, hak dan kewajiban termasuk risiko, sanksi yang harus dipikul jika para pihak tidak memenuhi kewajiban, penyelesaian perselisihan, pemutusan atau pengakhiran perjanjian dan pengembalian infrastruktur dan atau pengelolaanya (Pasal 10 ayat (2). 
Perpres No. 65 Tahun 2007 jo Perpres No. 13 Tahun 2010 telah menyempurnakan mekanisme kerjasama pembuatan perjanjian kerjasama (Cooperation Agreement) di atas dengan dibentuknya beberapa lembaga di tingkat pusat dengan nama Komite Kebijakan Percepatan Penyediaan Infrastruktur (KKPPI) yang bertugas melakukan koordinasi dengan intansi terkait dan memberikan jaminan yang diperlukan bagi Badan Usaha yang akan melakukan kerjasama. Selain KKPPI, terdapat pula lembaga dengan nama Unit Pusat Kerjasama Pemerintah dan Swasta atau Public Private Partnership Central Unit (P3CU) yang bertugas membantu dan memberikan nasihat kepada KKPPI dalam menyusun perencanaan kebijakan strategis yang menyangkut pengadaan infrastruktur publik.

Keberadaan lembaga lembaga ini, yang di katagorikan sebagai state auxiliary organ (lembaga yang sifatnya komplementer dalam pelaksanaan undang-undang ${ }^{22}$ tentunya akan sangat membantu pemerintah dalam mempercepat proses dan pencarian mitra kerjasama dan pelaksanaan berbagai peraturan peraturan yang berkaiatan dengan kerjasama, sehingga kerjasama yang dilakukan oleh pemerintah sesuai hukum yang berlaku. Namun sayang sekali di tingkat daerah, lembaga sejenis ini tidak ada dan tidak mendapat pengaturan. Padahal keberadaan lembaga seperti ini akan dapat membantu peme-rintah daerah agar membuat perjanjian kerjasama (cooperation agreement) tidak melanggar ketentuan hukum yang berlaku.

Pemerintah daerah dalam melakukan tindakan hukum sebagaimana diatur dalam UU No. 32 Tahun 2004 harus memperhatikan ketentuan hukum yang lainnya yang mengatur tentang pemindahtanganan kekayaan daerah. Ketentuan Pasal 45 ayat (2) UU No. 1 Tahun 2004 tentang Perbendaharaan Negara mengatur, bahwa:

"Pemindah tanganan kekayaan daerah melalui jual beli, hibah maupun penyertaan modal hanya dapat dilakukan setelah mendapat persertujuan DPRD. Itu ar-

22 Budi L Kagramanto, "Implementasi UU No.5 Tahun 1999 oleh KPPU", Jurnal IImu Hukum J ustitia, 2007, Poso: Fakultas Hukum Universitas Sintuwu Maroso, hlm. 2. tinya bahwa Pemerintah Daerah dapat melakukan kerjasama dengan pihak ketiga sepanjang mendapat persetujuan dari DPRD untuk memanfaatkan kekayaan Negara yang ada agar lebih produktif."

Sebagai pelaksanaan UU No.1 Tahun 2004, maka dikeluarkanlah Peraturan Pemerintah No. 6 Tahun 2006 tentang Pengelolaan Barang Milik Negara/ Daerah jo Peraturan Pemerintah No. 38 Tahun 2008. Peraturan Pemerintah ini semakin menegaskan tentang bentuk perjanjian yang boleh dilakukan pemerintah daerah dalam rangka memanfaatkan kekayaan negara, meliputi: sewa, pinjam pakai, kerjasama pemanfaatan dan bangun guna serah dan bangun serah guna (Pasal 20 UU No. 1 Tahun 2004).

Ketentuan Pasal 27 Peraturan Pemerintah No. 6 Tahun 2006, mengatur bahwa bangun guna serah dan bangun serah guna barang milik negara/daerah dapat dilaksanakan dengan beberapa persyaratan. Pertama, pengguna barang memerlukan bangunan dan fasilitas bagi penyelenggaraan pemerintahan negara/ daerah untuk kepentingan pelayanan umum dalam rangka penyelenggaraan tugas pokok dan fungsi; kedua, tidak tersedia dana dalam Anggaran Pendapatan dan Belanja Negara/ Daerah untuk penyediaan bangunan dan fasilitas dimaksud; dan ketiga, bangun guna serah dan bangun serah guna dilaksanakan oleh pengelola barang setelah mendapat persetujuan gubernur/bupati/ walikota;

Salah satu sumber hukum yang tidak boleh diabaikan dalam membuat perjanjian kerjasama antara pemerintah daerah dengan pihak swasta atau badan hukum swasta adalah Keputusan Pre-siden No. 80 Tahun 2003 Tentang Pelaksanaan Pengadaan Barang/J asa Pemerintah yang telah dirubah dengan Perpres No. 54 Tahun 2010. Ketentuan Pasal 3 Perpres No. 54 Tahun 2010 tersebut diatur dua model pengadaan barang dan jasa yaitu dengan mempergunakan Penyedia Barang/J asa dan dengan swakelola.

Berdasarkan uraian di atas jelaslah bahwa payung hukum kerjasama pemerintah dengan pihak swasta dalam membuat perjanjian build and transfer untuk membangun fasilitas umum belum mendapat pengaturan yang khu- 
sus. Kelihatannya Pemerintah kurang menyadari bahwa pembaruan hukum yang dapat menunjang terciptanya pembangunan nasional yang berkelanjutan seharusnya dilakukan secara lebih selektif. ${ }^{23}$ Akibat perbedaan hukum, budaya dan social, mengakibatkan masyarakat dunia menginginkan sutu hukum yang dapat mengatur kehidupan global. ${ }^{24}$ Namun demikian, dapat saja peraturan yang terkait dengan kemitraan dan kerjasama daerah dipergunakan dengan menggunakan penafsiran hukum (interpretasi) maupun analogi.

Penggunaan interpretasi dan analogi tidak selamanya mudah, karena beberapa ketentuan atau pasal yang menyangkut proses kerjasama tersebut mengandung kekaburan norma terutama yang menyangkut tentang proses penentuan mitra kerjasama tersebut, apakah meIalui tender atau penunjukan langsung. Interpretasi hukum ini muncul, karena menurut Peraturan Presiden No. 67 Tahun 2005 tentang Perjanjian Kerjasama Pemerintah dengan Badan Usaha dalam Penyediaan Infrastruktur Publik, Peraturan Pemerintah No. 50 Tahun 2007 tentang Kerjasama dengan pihak ketiga dan terakhir dengan Perpres No. 13 Tahun 2010 sebagai Pengganti Perpres No. 67 Tahun 2005 terkesan bahwa Pemerintah (Daerah) dapat menunjuk langsung mitra kerjasama yaitu badan usaha yang memprakarsi proyek tersebut atau badan usaha yang merancang pembangunan infrastruktur. Pemerintah (daerah) baru melakukan pelelangan umum apabila pihak yang merancang proyek tersebut tidak berhasil melakukan negosiasi terhadap kesepakatan harga dan persyaratan lainnya yang diatur dalam rancangan kerjasama. Hal ini artinya bahwa proses pelelangan bukanlah menjadi pilihan utama padahal menurut Perpres No. 54 Tahun 2010 bahwa semua proses pengadaan barang dan jasa yang nilainya di atas Rp. 100.000.000 (seratus juta rupiah) harus melalui tender.

23 St Laksanto Utomo, "Pembaharuan Hukum Penanaman Modal Undang-undang No. 25 Tahun 2007", J urnal Supremasi Hukum, Volume III No.1, Oct-Maret 2010, J akarta: Universitas Sahid J akarta, hlm. 5.

24 Liza Marina, "Budaya Hukum Kontrak Bisnis Internasional", J urnal Supremasi Hukum, Vol. 1 No.2, Apr-Sept 2008, J akarta: Universitas Sahid J akarta, hlm. 19.
Kekaburan norma bahkan konflik norma tersebut mengakibatkan dalam praktik proses perjanjian build and transfer yang dilakukan oleh Pemda Lombok Barat dengan Pihak Swata ada yang dilakukan dengan penunjukan langsung, seperti dalam Pembangunan Rumah Sakit Daerah dan ada yang melalui proses tender, seperti dalam pembangunan Pasar Umum Narmada (Surat Perjanjian Kerjasama antara Pemda Lombok Barat dengan PT. Damai Indah No. 161/ VL1VIII/ 2003 dan No. 045/610/TU/ VIII/ 2003, 8 Agustus 2003).

Persoalan lain yang muncul dalam praktik akibat kekaburan norma adalah ketidak jelasan tentang siapa yang menjadi subyek dan berhak menandatangani kontrak kerjasama. Hal ini terjadi, karena diberbagai peraturan muncul istilah menteri (UU No. 1 Tahun 2004 tentang Perbendaharaan Negara), Kepala Daerah ( UU No. 32 Tahun 2004 tentang Pemerintahan Daerah), sekretaris daerah (selaku pengelola barang daerah) dan kepala dinas (selaku penggguna barang milik daerah-PP No. 6 Tahun 2006 tentang Pengelolaan Barang Milik Negara/Daerah), badan kontrak pemerintah (Governement Contracting Agency) sebagaimana diatur dalam Perpres No. 13 Tahun 2010.

Kekaburan hukum lainnya adalah dalam bentuk apakah akta perjanjian Kerjasama itu dituangkan, apakah dalam bentuk akta notaris atau cukup akta di bawah tangan? Muh. Ilham Arisaputra dalam penelitiannya mengemukakan bahwa sebaiknya perjanjian kerjasama antara pemerintah dengan pihak swasta dalam bentuk akta notaris, agar mempunyai kekuatan hukum yang sempurna. ${ }^{25}$ Pilihan agar perjanjian kerjasama (cooperation agreement) dibuat notaris, agar perjanjian tersebut secara subtansi benarbenar memenuhi syarat subyektif dan obyektif dalam perjanjian dan memenuhi prinsip keseimbangan para pihak, dan menghindari format dan kontrak baku dari perjanjian yang dibuat pemerintah yang kurang memberikan ruang me-

25 Muh. Ilham Arisaputra, "Analisis Hukum Build, Operate, and Transfer Pada perjanj ian Bangun, Guna, Serah pada Investasi PT. Tosan Permai Dalam Rangka Revitalisasi Lapangan Karebosi", J urnal Penelitian Hukum, Vol. 1, No.1, September 2011, Makassar: Fakultas Hukum Universitas Hasanudin, hlm. 203. 
milih bagi kontraktor. ${ }^{26}$ Penggunaan perjanjian standar walaupun dapat menghemat waktu dan mempercepat proses terjadinya transaksi transaksi, namun demikian ditinjau dari aspek hukum, pengaplikasian perjanjian standar banyak pula menimbulkan masalah, terutama dalam pembuatan klausul dalam perjanjian yang cenderung mengutamakan pihak yang merancang. ${ }^{27}$ Oleh sebab itu pembuatan perjanjian kerjasama build and transfer dihindari dalam bentuk perjanjian standar.

Hasil penelitian penulis terhadap kontrak yang dibuat antara Pemerintah Daerah di NTB, bahwa akta perjanjian kemitraan build and transfer seluruhnya dibuat dalam bentuk akta yang tidak dibuat di notaris. Akibatnya bahwa berbagai format dan isi kontrak tersebut sangat bervariasi dan tidak memenuhi kaidah hukum kontrak yaitu legalitas para pihak yang membuat kontrak dan syarat-syarat yang tidak seimbang antara para pihak.

\section{Penutup Simpulan}

Beberapa simpulan yang dapat diberikan adalah sebagai berikut. Pertama, di Indonesia tidak ditemukan peraturan yang khusus mengatur tentang perjanjian kerjasama (cooperation agreement) yang berkaitan dengan build and transfer atau design and build; kedua, meskipun belum ada peraturan khusus, ternyata dalam praktek di Nusa Tenggara Barat, Pemerintah Daerah telah melakukan perjanjian kerjasama (cooperation agreement) yang sejenis build and transfer atau design and build yang dalam kontrak disebut full finance sharing; ketiga, sumber hukum yang dipergunakan dalam membuat perjanjian full finance sharing itu

26 Bambang Poerdiyatmono, "Asas Kebebasan Berkontrak (Contractvrijheid Beginselen) dan Penyalahgunaan Keadaan (Misbruik van Omstanddigheden) pada Kontrak J asa Kosntruksi", J urnal Tehnik Sipil, Volume 6 No.1, Oktober 2005, hlm 48.; Nanda Amalia, “Kontrak Baku dan Badan Penyelesaian Sengketa dalam Kontrak Bisnis Internasional", Suloh: jurnal Penelitian dan Pengkajian Hukum, Aceh: Fakultas Hukum Universitas Malikussaleh, Vol 3, No. 1 Tahun 2005, hlm. 76.

27 Hendra Tanu Atmadja, "Dinamika Hukum Perjanjian Yang Dikaitkan dengan Perjanjian Standar", Jurnal Supremasi Hukum, Jakarta: Universitas Sahid, Vol. V, No. 1, Oktober-Maret 2012, hlm. 1. adalah UU No. 1 Tahun 2004 tentang Perbendaharaan Negara, UU No. 32 Tahun 2004 tentang Pemerintahah Daerah yang masing-masing dilaksanakan dengan PP No. 6 Tahun 2006 dan Perpres No. 13 Tahun 2010 dengan menggunakan interpretasi dan analaogi dalam mengisi kekaburan dan kekosongan hukum yang ada.

\section{Saran}

Saran yang disampaikan adalah sebegai berikut. Pertama, perlu segera dibentuk peraturan hukum yang mengatur perjanjian kerjasama antara pemerintah dengan pihak swasta menyangkut penyediaan infrastruktur dalam bentuk undang-undang, sehingga dengan demikian multi tafsir terhadap berbagai peraturan yang selama ini tersebar di berbagai tempat dan tingkatan akan terhindari dan sekaligus akan menghindari terjadinya penerapan hukum yang keliru; dan kedua, perlu adanya lembaga yang khusus menangani persoalan kemitraan di daerah yang jika di pusat dinamakan Komite Kebijakan Percepatan Penyediaan Infrastruktur (KKPPI), maka di daerah dinamakan KKPPI-Daerah dan Pusat Kerjasama Pemerintah dan Swasta atau Public Private Partnership Central Unit (P3CU) yang di pusat berada di Bappenas, maka di Daerah dibentuk P3CPU-Daerah yang berada di bawah BAPPEDA.

\section{Daftar Pustaka}

Adha, Lalu Hadi. "Kontrak BOT Sebagai Perjanjian Kebijakan (Beleid Overeenskomst)". Jurnal Law Reform, Vol. 4 No. 1. 2009. Padang: Program Studi IImu Hukum (S2) Universitas Bung Hatta;

-.---.. “Kontrak Build Operate Transfer Sebagai Perjanjian Kebijakan Pemerintah Dengan Pihak Swasta". Jurnal Dinamika Hukum. Vol. 11 No.3. September 2011. Purwokerto: FH Unsoed;

Amalia, Nanda. "Kontrak Baku dan Badan Penyelesaian Sengketa dalam Kontrak Bisnis Internasional". Suloh: Jurnal Penelitian dan Pengkajian Hukum, Vol 3 No.1 Tahun 2005. Aceh: Fakultas Hukum Universitas Malikussaleh;

Anonim. 2006. Penyelenggaran Pemerintahan dan Pembangunan Daerah. Jakarta: BAPPENAS; 
Arisaputra, Muh. Ilham. "Analisis Hukum Build, Operate, and Transfer Pada perjanjian Ba-ngun, Guna, Serah pada Investasi PT. Tosan Permai Dalam Rangka Revitalisasi Lapangan Karebosi". Jurnal Penelitian Hukum. Vol. 1 No. 1. September 2011. Makassar: Fakultas Hukum Universitas Hasanudin;

Arsyad, Nurdjaman. 1992. Keuangan Negara. J akarta: Intermedia;

Arthur, Sullivan. "Economics: Principles in action", Journal Economic, August, 2003, Upper Saddle River: New J ersey Pearson Prentice Hall.;

Atmadja, Hendra Tanu. "Dinamika Hukum Perjanjian Yang Dikaitkan dengan Perjanjian Standar", J urnal Supremasi Hukum, Vol. V No. 1. Oktober-Maret 2012. Jakarta: Universitas Sahid;

Durbar, Singa. 2000. National Planing Commision, Kathmandu;.

Endeshaw, A. "Intellectual Property and the WIPO Development Agenda", Journal of Information Law and Technology, Special Issue, No, 1, J une, 2007, hlm. 15;

Eng, Tambosso P. "Fairness Opinion-Why or Why Not", J ournal Dailly, April, 2008;

Europen Comission (Directorate General for Energy and Transport) Contract No. NNE52002/ 52: OPET CHP/DH cluster: The role of Build Operate Transfer in Promoting RES project, Desember 2003;

Hagman, Donald G. "Public Planning and Control of Urban and Development". Cases and Material Journal, No.2 2008. West Publishing;

Indriati, Noer. "Perjanjian Internasional Oleh Daerah Sebagai Kewenangan Otonomi Daerah", J urnal Dinamika Hukum, Vol 10 No. 1, J anuari 2010, Purwokerto: FH Unsoed;

Jaya, Nyoman Marta. "Analisis Perbandingan Kerjasama Proyek Antara Sistem BOT dan Turn Key (Studi Kasus Proyek Multi Investmen PT.Pesero Pos Indonesia)". J urnal IImiah Tehnik Sipil; Vol. 12 No. 01. J anuari 2008;

J honson, Lyman PQ. "Corporate Officer and Business Jugmen Rule", Journal The Business Lawyer, Vol. 60, February 2005, Wa-shington and Lee University;

Kagramanto, Budi L. "Implementasi UU No.5 Tahun 1999 oleh KPPU", Jurnal IImu Hu- kum J ustitia, 2007, Poso: Fakultas Hukum Universitas Sintuwu Maroso;

Karz, Geral I and Stephen W Smith. "Build Operate Transfer. The Future of Public Construction". Journal of Construction Accounting and Taxation, March/ April 2003;

Kristiana, Yudi. "Ketika Hukum Tidak lagi Otentik". Jurnal Supremasi Hukum. Jakarta: Universitas Sahid, Vol IV No.1. Oct-Maret 2011;

Mahmudi. "Kemitraan Pemeritah Daerah dan Efektifitas Pelayanan Publik", Jurnal Sinergi-Kajian Bisnis dan Menejemen. Vol. 9 No.1, Januari 2007;

Marina, Liza. "Budaya Hukum Kontrak Bisnis Internasional". Jurnal Supremasi Hukum. Vol. 1 No. 2. April-September 2008, Jakarta: Universitas Sahid J akarta;

Nurjaman, Hari Nugraha. "Analisis Perbandingan Kemitraan Build Operate Transfer (BOT) dan Konsesi Pada Pembiayaa Pada Pem-bangunan Boulevars J odoh dan Rumah Susun Sewa Kota Batam", J urnal Rekayasa Dan Menej emen Pembiayaan Perumahan, Vol.1 No.1, Tahun 2008J akarta: Universitas Persada Indonesia YAl;

Poerdiyatmono, Bambang. "Asas Kebebasan Berkontrak (Contractvrijheid Beginselen) dan Penyalahgunaan Keadaan (Misbruik van Omstanddigheden) pada Kontrak J asa Kos-ntruksi". Jurnal Tehnik Sipil. Vol. 6 No. 1. Oktober 2005;

Sari, Widya. "Asas Kebebasan Berkontrak Dalam Hukum Perjanjian Indonesia". Jurnal IImiah Pendidikan, Sejarah dan Sosial Budaya. Vol. 10 No. 3. Januari 2009;

Seligman, Edwin RA. 2005. Encyclopaedia of the social sciences. Vol. 11, New York: the Macmillan;

Tarigan, Antonius. "Tranformasi Model New Governance Sebagai Kunci Menuju Optimalisasi Pelayanan Publik di Indonesia". Jurnal Usahawan. No. 02 Th XXXII. Februari 2003;

Utomo, St Laksanto. "Pembaharuan Hukum Penanaman Modal Undang-undang No. 25 Tahun 2007". Jurnal Supremasi Hukum. Vol. III No. 1, Oktober-Maret 2010. J akarta: Universitas Sahid J akarta;

Waryhas, Maryann. "It Looks Like a Good DealBut Is It a Fair Deal", The Journal Publication of Stout Risius Ross, Fall 2005. 
